\title{
Cordilleran granitoids and restite entrainment: A thermodynamic modelling
}

\author{
M.GARCIA-ARIAS $^{1 *}$, J.S.PUERTO-LEÓN ${ }^{1}$, C.D. \\ RONDEROS-ALMEIDA ${ }^{1}$
}

${ }^{1}$ Dept. Geociencias, Univ. Los Andes, Cr 1 \#18A-12, Bogotá, Colombia ((*correspondence: m.garcia@uniandes.edu.co; js.puerto11@uniandes.edu.co;

cd.ronderos@uniandes.edu.co)

The recent paradigm of formation of Cordilleran batholiths imply ascension of diapirs of melted sediments and basaltic crust, their relamination to the continental crust and segregation of melts/magmas from the relaminated body into the crust [1]. In this scenario, new diapirs may heat and melt previously relaminated ones and the segregated magmas may entrain variable amounts of a peritectic-rich restite [2], contributing, together with fractional crystallization, to the compositional variability of the batholiths.

Thermodynamic calculations on the partial melting of several source rocks at $1.0 \mathrm{GPa}$ have been made with the software Perple_X [3] to evaluate this possibility. The starting compositions ranged from basaltic andesite to andesite, high$\mathrm{Mg}$ andesite and dacite, to cover a wide range of sedimentbasalt proportions in the diapirs. The modelled melting process included the pulsed segregation of melt every time melt amount reached 7 wt.\%. The modeled magmas contained variable proportions of melt and minerals (from 100:0 to 60:40, respectively) and of peritectic and reactant minerals (from 100:0 to $0: 100)$ at the temperatures of segregation. The trends of several elements and element ratios of the modelled magmas formed by increasing entrained mineral amounts, versus maficity $(\mathrm{FeO}+\mathrm{MgO})$, were compared to those of Cordilleran granitoids to determine the source composition and peritectic:reactant proportions that produce the best match.

The results indicate that the magmas with $\sim 80 \%$ peritectic minerals in the entrained mineral assemblage, generated at $\mathrm{T}<$ $875{ }^{\circ} \mathrm{C}$ from the andesite and basaltic andesite source compositions have the best fit with the trends of the granites except for $\mathrm{K}_{2} \mathrm{O}$ and $\mathrm{Al}_{2} \mathrm{O}_{3}$. Magmas from the dacite source have slightly positive $\mathrm{A} / \mathrm{CNK}$ trends and magmas from high$\mathrm{Mg}$ andesites have a too high $\mathrm{Mg \#}$.

The results of this work support the hypothesis that restite entrainment may contribute to the compositional variability of the Cordilleran granitoids, but more rigorous calculations

[1] Castro (2014) Geosci. Front. 5, 63-75. [2] Clemens et al. (2011) Lithos 126, 174-181. [3] Connolly (2009) G-cubed 10, Q10014. 